\title{
Peran Self-Compassion terhadap Kualitas Hidup Profesional: Studi pada Perawat Jiwa
}

\author{
Anggita Kesumaputri ${ }^{1}$, Hamidah ${ }^{1}$, M. Shalehuddin ${ }^{2}$ \\ ${ }^{1}$ Fakultas Psikologi Universitas Airlangga, ${ }^{2}$ RSJ Dr. Radjiman Wediodiningrat Lawang \\ email: anggita.kesumaputri-2016@psikologi.unair.ac.id
}

\begin{abstract}
Abstrak
Artikel INFO

Diterima:14 Juli 2021

Direvisi 06 Spetember 2021

Disetujui:28 September 2021

DOI:

http://dx.doi.org/10.24014/ jp.v14i2.13625

Perawat jiwa memiliki beban pekerjaan yang mengakibatkan mereka rentan mengalami burnout dan secondary traumatic stress yang dapat menurunkan kualitas hidup profesional, kemudian berdampak pada kinerja dan kesejahteraan pribadi mereka. Penelitian ini bertujuan untuk mengetahui secara empiris peran self-compassion terhadap kualitas hidup profesional pada perawat jiwa yang bekerja di rumah sakit jiwa. Tipe penelitian ini adalah survei dengan model cross-sectional. Subjek merupakan 89 perawat yang bekerja di RSJ Dr. Radjiman Wediodiningrat Lawang, dipilih melalui teknik purposive sampling. Alat ukur yang digunakan adalah Self-Compassion Scale (SCS) dan Professional Quality of Life Scale versi 5 (ProQOL 5). Hasil analisis data dengan regresi linear sederhana menunjukkan bahwa self-compassion memiliki pengaruh yang signifikan terhadap aspek-aspek kualitas hidup profesional, yakni compassion satisfaction $(B=0,202, p<0,001)$, burnout $(B=-0,225, p<0,001)$, dan secondary traumatic stress $(B=-0,239, p<0,001)$. Penelitian ini menunjukkan bahwa selfcompassion berperan dalam memprediksi kualitas hidup profesional pada perawat jiwa. Edukasi mengenai self-compassion untuk perawat jiwa dapat menjadi salah satu pilihan intervensi untuk meningkatkan kualitas hidup profesional mereka.
\end{abstract}

Kata Kunci: perawat jiwa; kualitas hidup profesional; self-compassion

\section{The Role of Self-Compassion on Professional Quality of Life: A Study on Mental Health Nurses}

\begin{abstract}
Mental health nurses have a workload that makes them vulnerable to burnout and secondary traumatic stress which can reduce professional quality of life, impacting their performance and personal well-being. This study aimed to empirically determine the role of self-compassion on professional quality of life of mental health nurses who work in mental health hospital. This is a surveyresearch with a cross-sectional model. Subjects were 89 nurses who work at Dr. Radjiman Wediodiningrat Lawang Mental Health Hospital, selected through purposive sampling technique. The instruments used were Self-Compassion Scale (SCS) and Professional Quality of Life Scale version 5 (ProQOL 5). The results of data analysis with simple linear regression showed that self-compassion has a significant effect on aspects of professional quality of life, namely compassion satisfaction $(B=0,202, p<0.001)$, burnout $(B=-0,225, p<0.001)$, and secondary traumatic stress $(B=-0,239, p<0.001)$. This study shows that self-compassion plays a role in predicting the professional quality of life of mental health nurses. Education about self-compassion for mental health nurses can be an intervention option to improve their professional quality of life.
\end{abstract}

Keywords: mental health nurses; professional quality of life; self-compassion

\section{Pendahuluan}

Perawat jiwa merupakan salah satu bagian penting dalam pelayanan kesehatan jiwa, khususnya di rumah sakit jiwa. Salah satu pekerjaan yang dilakukan yakni pemberian asuhan keperawatan, menuntut perawat jiwa untuk mampu membangun hubungan interpersonal dan komunikasi yang baik dengan pasien, hadir secara utuh dari segi fisik maupun psikologis untuk memenuhi kebutuhan pasien (Yusuf, Fitryasari, Nihayati, \& Tristiana, 2019). Namun, selama bekerja perawat jiwa tidak terlepas dari tantangan dan permasalahan pekerjaan.

Perawat jiwa menghabiskan sebagian besar waktu untuk menyediakan perawatan 
bagi pasien dengan kondisi mental yang kompleks. Mereka berinteraksi secara langsung dan terus-menerus dengan pasien, dan interaksi ini dapat terjadi dalam jangka waktu lama. Terlebih lagi, perawat jiwa dihadapkan dengan perilaku pasien yang tidak terduga (Joubert \& Bhagwan, 2018). Perawat jiwa juga sangat berisiko mendapatkan perilaku agresif dan kekerasan dari pasien (Aji \& Ambarini, 2014; Yosep, Putit, Hazmi, \& Mediani, 2016). Selain merawat pasien, perawat jiwa memiliki tugas administrasi yang harus diselesaikan (Hamaideh, 2012). Tantangan lain yang dihadapi yaitu kurangnya apresiasi dan adanya pandangan negatif mengenai pekerjaan sebagai perawat jiwa di masyarakat dan kalangan sesama profesi perawat (Sabella \& Fay-Hillier, 2014).

Beban dan tantangan pekerjaan membuat perawat jiwa berada dalam situasi penuh tekanan kemudian menimbulkan stres dan trauma (Amelia, Iswantoro, \& Chrisnawati, 2017; Turgoose \& Maddox, 2017; Varghese, 2020). Hal ini mengakibatkan mereka rentan mengalami compassion fatigue (Kaur et al., 2018 dalam Handini, Patarru', Weu, Heryyanoor, \& Purwanza, 2019) yang dapat menurunkan kualitas hidup profesional.

Kualitas hidup profesional adalah kualitas yang dirasakan individu terkait dengan pekerjaannya sebagai seorang penolong (Stamm, 2010). Kualitas hidup profesional meliputi dua aspek, yaitu 1) compassion satisfaction sebagai aspek positif dan 2) compassion fatigue sebagai aspek negatif (Stamm, 2010).

Compassion satisfaction adalah kondisi ketika perawat jiwa merasakan pemenuhan diri dan kebahagiaan karena dapat menolong orang lain dan melakukan pekerjaannya dengan baik. Compassion fatigue dibagi menjadi dua, yakni burnout dan secondary traumatic stress. Burnout adalah kelelahan fisik, emosional, dan mental disebabkan oleh keterlibatan jangka panjang dalam situasi yang menguras emosi dan berangsur-angsur mengakibatkan kesulitan dalam melakukan pekerjaan secara efektif. Secondary traumatic stress adalah tekanan, kecemasan, dan rasa takut yang muncul karena membantu orang yang secara langsung mengalami situasi traumatis dan menyaksikan pengalaman traumatis orang yang dibantu.

Kualitas hidup profesional yang baik tergambar dari adanya compassion satisfaction. Compassion satisfaction yang didapat dari pekerjaan memberikan makna dan tujuan hidup bagi perawat jiwa, membuat mereka terlibat secara utuh dan lebih percaya diri dalam melakukan tugas. Compassion satisfaction juga memunculkan koordinasi tim yang baik, sehingga tercipta lingkungan pekerjaan yang positif (Sacco \& Copel, 2018). Coetzee dan Klopper (2010) mengatakan ketika kualitas hidup profesional individu baik, maka ia akan lebih berkembang dalam pekerjaannya. Meskipun begitu, untuk mencapai kualitas hidup profesional yang baik tidaklah mudah karena perawat jiwa juga dapat merasakan compassion fatigue.

Studi yang dilakukan oleh Hegney dan kawan-kawan (2015) menemukan bahwa burnout dan secondary traumatic stress berhubungan secara signifikan dengan tingkat depresi dan kecemasan. Compassion fatigue yang dialami perawat dapat menyebabkan meningkatnya penyakit fisik dan izin sakit, tingginya tingkat turnover, dan berkurangnya produktivitas (Murray, 2019). Studi lain mengungkap bahwa burnout dapat memengaruhi kemampuan individu untuk menunjukkan rasa belas kasih terhadap pasien dan mengurangi kepuasan kerja (Farquharson et al., 2013; Young Hee \& Jong Kyung, 2012 dalam Durkin, Beaumont, Hollins Martin, \& Carson, 2016). Compassion fatigue juga diketahui berkorelasi dengan menurunnya kepuasan dan keselamatan pasien (Garman, et al., 2002; Halbesleben, et al., 2008 dalam Potter et al., 2010). Oleh karena itu, diperlukan untuk mengetahui 
faktor-faktor yang dapat memengaruhi kualitas hidup profesional.

Salah satu faktor yang dapat memengaruhi kualitas hidup profesional yaitu self-compassion. Self-compassion adalah sikap terbuka terhadap penderitaan, kegagalan, atau kekurangan diri, berusaha meringankan penderitaan yang dialami dengan kebaikan, memberikan pemahaman yang tidak menghakimi, dan memandang pengalaman tersebut sebagai pengalaman manusia yang umum (Neff, 2003a).

Self-compassion mencakup tiga aspek, yaitu 1) self-kindness vs self-judgement, 2) common humanity vs isolation, dan 3) mindfulness vs over-identification (Neff, 2003a). Self-kindness adalah bersikap baik dan memahami diri sendiri dibandingkan terlalu mengkritik diri (self-judgement). Common humanity yakni memandang peristiwa yang dialami sebagai bagian dari pengalaman manusia yang umum dibandingkan merasa terisolasi (isolation). Mindfulness adalah menyadari pikiran dan perasaan atas pengalaman saat ini dengan seimbang dibandingkan terlalu tenggelam dalam perasaan negatif (over-identification).

Self-compassion berperan dalam melunakkan reaksi individu ketika mengalami peristiwa buruk maupun ketika menyaksikan penderitaan orang lain, sehingga individu mampu merespon peristiwa tersebut dengan keseimbangan emosi yang lebih besar dan dengan sudut pandang objektif (Abaci \& Arda, 2013; Neff \& Pommier, 2013). Alhasil, walaupun perawat jiwa mengalami kejadian buruk selama memberikan perawatan pada pasien, ia tetap merasakan kepuasan dari pekerjaannya. Selain itu, dengan reaksi emosi yang adaptif serta sudut pandang objektif, perawat jiwa tidak mudah mengalami stres berlebihan (Germer \& Neff, 2013). Hal ini memperkecil risiko terjadinya compassion fatigue.
Penelitian Duarte dan Pinto-Gouveia (2017) mengungkap bahwa self-compassion dapat memprediksi tingkat compassion satisfaction yang lebih tinggi dan compassion fatigue yang lebih rendah. Durkin dan kawankawan (2016) menemukan bahwa tingkat selfcompassion tinggi mendorong peningkatan pada kualitas hidup dan kesejahteraan, serta ketahanan yang lebih besar terhadap stres kerja. Studi yang dilakukan Duarte dan kawan-kawan (2016) mengungkap bahwa kemampuan untuk memandang pengalaman negatif secara sadar (mindful) berkontribusi terhadap compassion satisfaction. Kedua penelitian tersebut menyebutkan bahwa kecenderungan mengkritik dan mengisolasi diri, serta terlalu tenggelam dalam pengalaman negatif meningkatkan kerentanan terjadinya compassion fatigue. Penelitian kualitatif dengan subjek perawat muda mengungkap bahwa menerapkan selfcompassion di tempat kerja membuat mereka mampu memberikan perawatan yang lebih baik dan menghadapi permasalahan dengan bijak (McPhee, 2019).

RSJ Dr. Radjiman Wediodiningrat Lawang (RSJ Lawang) adalah salah satu rumah sakit jiwa yang menjadi rujukan utama di Jawa Timur (Hikmah, 2015). Penelitian sebelumnya terhadap perawat jiwa di RSJ Lawang menyebutkan bahwa perilaku agresi yang dilakukan pasien membuat perawat mengalami stres (Aji \& Ambarini, 2014; Muhith, Fardiansyah, \& Mawaddah, 2018). Hal ini berdampak pada kecemasan dan berkurangnya sensitivitas terhadap orang lain, terutama pasien. Selain itu, kondisi pasien yang sangat tidak stabil terkadang membuat perawat merasa takut dan tidak mampu menangani pasien, serta kelelahan jika jumlah pasien yang ditangani cukup banyak (Kholifah, Soeharto, \& Supriati, 2016).

Hasil wawancara terhadap beberapa perawat jiwa di RSJ Lawang mengungkap bahwa tantangan pekerjaan yang dihadapi perawat antara lain perilaku pasien yang 
tidak terduga, pasien tidak mau makan, dan melawan pada perawat. Di samping itu, perubahan kebijakan rumah sakit yang dapat terjadi secara cepat dan mendadak. Hal ini cukup menyulitkan perawat karena harus bisa beradaptasi dengan cepat.

Sampai saat ini, mayoritas studi tentang kualitas hidup profesional di Indonesia berfokus pada kaitannya dengan faktor demografis dan faktor terkait pekerjaan (Amelia et al., 2017; Andriani, Haryanti, \& Rustiyaningsih, 2017; Debora, Ahsan, \& Kartikawatiningsih, 2017). Penelitian mengenai hubungan faktor psikologis, khususnya self-compassion dengan kualitas hidup profesional pada perawat belum banyak ditemukan dalam publikasi.

Berdasarkan penjelasan di atas, hipotesis yang diajukan dalam penelitian ini yaitu terdapat pengaruh self-compassion terhadap kualitas hidup profesional pada perawat jiwa di RSJ Dr. Radjiman Wediodiningrat Lawang.

\section{Metode}

Penelitian ini telah melalui proses kaji etik dan mendapatkan persetujuan layak etik (LB.02.03/XXVII.5.7/8282/2020) dari Komisi Etik Penelitian Kesehatan RSJ Dr. Radjiman Wediodiningrat Lawang.

\section{Subjek}

Responden dalam penelitian ini adalah 89 perawat jiwa yang bekerja di Rumah Sakit Jiwa Dr. Radijman Wediodiningrat Lawang (RSJ Lawang). Subjek dipilih menggunakan teknik purposive sampling dengan kriteria yakni laki-laki atau perempuan yang telah menyelesaikan pendidikan keperawatan minimal jenjang Diploma III dan bekerja sebagai perawat jiwa di RSJ Lawang. Pengumpulan data menggunakan kuesioner.

\section{Pengukuran}

Variabel yang diteliti adalah selfcompassion dan kualitas hidup profesional. Self-compassion merupakan sikap terbuka terhadap penderitaan atau kekurangan diri, berusaha meringankannya dengan kebaikan, memberikan pemahaman yang tidak menghakimi, dan memandang pengalaman tersebut sebagai pengalaman manusia yang umum (Neff, 2003a). Kualitas hidup profesional dapat diartikan sebagai persepsi individu terkait pekerjaannya sebagai penolong (Stamm, 2010).

Instrumen yang digunakan untuk mengukur self-compassion yaitu SelfCompassion Scale (SCS) yang telah diterjemahkan ke dalam bahasa Indonesia oleh Khamaisya (2019), yang meliputi tiga aspek yaitu self-kindness vs selfjudgement, common humanity vs isolation, dan mindfulness vs over-identification (Neff, 2003b). Skala ini terdiri dari 26 aitem, berbentuk skala Likert dengan 5 pilihan jawaban yakni Tidak Pernah (TP), Jarang (JR), Kadang-kadang (KD), Sering (SR), dan Selalu (SL). Beberapa contoh aitem dalam skala ini adalah: "Saya menghakimi kekurangan yang saya miliki"; "Saya mencoba untuk melihat kegagalan sebagai bagian dari kehidupan"; dan "Saya mencoba untuk melihat situasi secara seimbang ketika hal yang menyakitkan menimpa saya". Pengukuran reliabilitas skala dengan Cronbach's a menunjukkan nilai koefisien a sebesar 0,891 .

Tabel 1. Karakteristik Demografis Subjek Penelitian ( $N=89)$

\begin{tabular}{c|c|c}
\hline Demografis & N & $\%$ \\
\hline Jenis Kelamin & & \\
Laki-laki & 31 & $34,8 \%$ \\
Perempuan & 58 & $65,2 \%$ \\
\hline
\end{tabular}




\begin{tabular}{l|c|c}
\hline Demografis & $\mathbf{N}$ & $\%$ \\
\hline Usia & & \\
\multicolumn{1}{l|}{ 25-40 tahun } & 51 & $57,3 \%$ \\
41-57 tahun & 38 & $42,7 \%$ \\
Tingkat Pendidikan & & \\
D3 & 38 & $42,7 \%$ \\
D4 & 2 & $2,2 \%$ \\
S1 & 47 & $52,8 \%$ \\
S2 & 2 & $2,2 \%$ \\
\hline Lama Bekerja & & \\
5-15 tahun & 11 & $12,4 \%$ \\
>15 tahun & 43 & $48,3 \%$ \\
PNS & 35 & $39,3 \%$ \\
Non PNS & & \\
\hline Status Kepegawaian & 78 & $87,6 \%$ \\
\hline
\end{tabular}

Kualitas hidup profesional diukur menggunakan Professional Quality of Life Scale versi 5 (ProQOL 5) yang telah diterjemahkan ke dalam bahasa Indonesia oleh Eka dan kawan-kawan (2016). Skala ini terdiri dari 30 aitem yang dibagi menjadi 10 aitem untuk masing-masing dari tiga aspek, yaitu compassion satisfaction, burnout, dan secondary traumatic stress (Stamm, 2009). ProQOL 5 berbentuk skala Likert yang memiliki lima pilihan jawaban, yakni Tidak Pernah (TP), Jarang (JR), Kadang-kadang (KD), Sering (SR), dan Sangat Sering (SS). Beberapa contoh aitem dalam skala ini yaitu: "Saya merasa puas ketika saya dapat merawat orang lain"; "Saya merasa kewalahan karena beban kerja seperti tidak ada habisnya"; dan "Saya merasa tertekan karena menghadapi pengalaman traumatis yang dialami oleh orang yang saya rawat". Pengukuran reliabilitas skala menggunakan Cronbach's $\alpha$. ProQOL 5 menunjukkan nilai a sebesar 0,660. Subskala compassion satisfaction memiliki nilai a sebesar 0,877 . Subskala burnout memiliki nilai a sebesar 0,743 . Subskala secondary traumatic stress memiliki nilai a sebesar 0,757 . Salah satu aitem yang termasuk dalam subskala burnout dikeluarkan karena memiliki nilai korelasi aitem total kurang dari 0,3 .

\section{Analisis Data}

Teknikanalisis datayang digunakanadalah statistik deskriptif untuk menggambarkan karakteristik demografis responden dan regresi linear sederhana untuk mengetahui pengaruh self-compassion terhadap kualitas hidup profesional. Analisis data dilakukan dengan program software statistik Jamovi 1.2.7 for Windows.

\section{Hasil}

Sampel dalam penelitian ini adalah 89 perawat jiwa di RSJ Lawang. Rentang usia responden yakni antara 25-57 tahun dengan mayoritas berusia 25-40 tahun (57,3\%). Sebagian besar responden adalah perempuan $(65,2 \%)$, memiliki latar belakang pendidikan S1 $(53,8 \%)$, telah bekerja sebagai perawat jiwa selama 5-15 tahun (48,3\%), dan berstatus sebagai Pegawai Negeri Sipil (PNS) $(87,6 \%)$. Data demografis responden disajikan dalam Tabel 1. 
Tabel 2. Statistik Deskriptif Self-Compassion dan Kualitas Hidup Profesional

\begin{tabular}{|c|c|c|c|c|c|c|}
\hline \multicolumn{2}{|l|}{ Variabel } & $\mathbf{N}$ & Min & Maks & Mean & SD \\
\hline \multicolumn{2}{|c|}{ Self-Compassion } & 89 & 67 & 128 & 101,92 & 11,95 \\
\hline \multirow{3}{*}{$\begin{array}{l}\text { Kualitas } \\
\text { Hidup } \\
\text { Profesional }\end{array}$} & $\begin{array}{l}\text { Compassion } \\
\text { Satisfaction }\end{array}$ & 89 & 31 & 50 & 42,52 & 4,35 \\
\hline & Burnout & 89 & 10 & 26 & 16,2 & 3,7 \\
\hline & $\begin{array}{l}\text { Secondary } \\
\text { Traumatic Stress }\end{array}$ & 89 & 10 & 33 & 18,28 & 4,51 \\
\hline
\end{tabular}

Hasil analisis deskriptif dapat dilihat pada Tabel 2. Skor self-compassion berada pada rentang 67-128 dengan rata-rata sebesar 101,92 (SD=11,95). Mayoritas responden memiliki self-compassion dalam kategori sedang (68,5\%). Analisis deskriptif kualitas hidup profesional menunjukkan bahwa aspek compassion satisfaction memiliki rentang skor 31-50 dengan rata-rata sebesar 42,52 $(S D=4,35)$. Mayoritas skor termasuk ke dalam kategori tinggi $(55,1 \%)$. Aspek burnout memiliki skor dalam rentang 10-26 dengan rata-rata sebesar 16,2 $(S D=3,7)$. Skor burnout paling banyak ada di kategori rendah $(95,5 \%)$. Skor pada aspek secondary traumatic stress memiliki rentang antara 10-33 dengan ratarata sebesar 18,28 $(S D=4,51)$. Sebagian besar skor berada dalam kategori rendah $(86,5 \%)$.

Hasil uji asumsi menunjukkan bahwa residual data berdistribusi normal dengan nilai signifikansi dari Saphiro-Wilk lebih dari 0,05. Uji linearitas menunjukkan bahwa self-compassion, compassion satis- faction, burnout, dan secondary traumatic stress memiliki hubungan yang linear. Uji homogenitas varians menunjukkan bahwa varians residual memenuhi asumsi homoskedasdisitas. Selanjutnya, data outlier dalam penelitian ini dapat diabaikan karena nilai rata-rata pada Cook's Distance kurang dari 1.

Uji korelasi dalam penelitian ini menggunakan teknik korelasi Spearman's Rank. Hasil pengujian menunjukkan bahwa self-compassion dan compassion satisfaction memiliki nilai korelasi sebesar 0,575. Selfcompassion dan burnout memiliki nilai korelasi sebesar -0,683. Self-compassion dan secondary traumatic stress memiliki nilai korelasi sebesar $-0,647$. Semua hasil uji korelasi tersebut menunjukkan nilai signifikansi kurang dari 0,001.

Hasil yang didapatkan dari uji regresi selfcompassion terhadap aspek-aspek kualitas hidup profesional adalah sebagai berikut. Berdasarkan Tabel 3, hasil

Tabel 3. Hasil Analisis Kecocokan Model Regresi

\begin{tabular}{lcccccc}
\hline \multicolumn{1}{c}{ Model } & & \multicolumn{5}{c}{ Overall Model Test } \\
\hline \multicolumn{1}{c}{ Self-Compassion ${ }^{*}$ Compassion } & $\mathbf{R}^{\mathbf{2}}$ & $\mathbf{F}$ & df1 & df2 & $\mathbf{p}$ \\
\hline $\begin{array}{l}\text { Satisfaction } \\
\text { Self-Compassion *Burnout }\end{array}$ & 0,554 & 0,307 & 38,467 & 1 & 87 & $<, 001$ \\
\hline $\begin{array}{l}\text { Self-Compassion *Secondary Traumatic } \\
\text { Stress }\end{array}$ & 0,727 & 0,529 & 97,585 & 1 & 87 & $<, 001$ \\
\hline
\end{tabular}


Tabel 4. Hasil Analisis Koefisien Model Regresi Self-Compassion terhadap Compassion Satisfaction

\begin{tabular}{lcccccc}
\hline \multicolumn{7}{c}{$\begin{array}{c}95 \% \text { Confidence } \\
\text { Interval }\end{array}$} \\
\hline \multicolumn{1}{c}{ Predictor } & B & SE & Lower & Upper & $\mathbf{t}$ & $\mathbf{p}$ \\
\hline $\begin{array}{l}\text { Intercept } \\
\begin{array}{l}\text { Self- } \\
\text { Compassion }\end{array}\end{array}$ & 21,970 & 3,337 & 15,338 & 28,603 & 6,584 & $<, 001$ \\
\hline
\end{tabular}

Tabel 4. Hasil Analisis Koefisien Model Regresi Self-Compassion terhadap Compassion Satisfaction

\begin{tabular}{|c|c|c|c|c|c|c|}
\hline \multirow[b]{2}{*}{ Predictor } & \multirow[b]{2}{*}{ B } & \multicolumn{3}{|c|}{$\begin{array}{c}95 \% \text { Confidence } \\
\text { Interval }\end{array}$} & \multirow[b]{2}{*}{$\mathbf{t}$} & \multirow[b]{2}{*}{$p$} \\
\hline & & SE & Lower & Upper & & \\
\hline
\end{tabular}

analisis kecocokan model regresi self- traumatic stress mendapatkan hasil bahwa compassion terhadap compassion satisfaction model cocok untuk menggambarkan data menunjukkan bahwa model cocok untuk $(F(1,87)=58,653 ; p<0,001)$ dan memiliki menggambarkan data $\left(F(1,87)=38,467 ; p<\right.$ nilai koefisien determinasi $\left(R^{2}\right)$ sebesar 0,403 $0,001)$ dan memiliki nilai koefisien determinasi yang berarti variabel self-compassion dapat $\left(R^{2}\right)$ sebesar 0,307 yang berarti variabel self- menjelaskan $40,3 \%$ varians dari secondary compassion dapat menjelaskan $30,7 \%$ varians traumatic stress. dari compassion satisfaction. Hasil analisis kecocokan model regresi self-compassion terhadap burnout menunjukkan bahwa model cocok untuk menggambarkan data $(F(1,87)$ $=97,585 ; p<0,001)$ dengan nilai koefisien determinasi $\left(R^{2}\right)$ sebesar 0,529 yang artinya self-compassion dapat menjelaskan 52,9\% varians dari burnout. Uji kecocokan model regresi self-compassion terhadap secondary

Hasil analisis koefisien model regresi dapat dilihat pada Tabel 4, 5, dan 6. Berdasarkan Tabel 4, dapat diketahui bahwa self-compassion menghasilkan pengaruh signifikan yang bersifat positif dan lemah $(B$ $=0,202, \mathrm{Cl}_{95}=[0,137 ; 0,266], S E=0,033, p$ $<0,001)$ terhadap compassion satisfaction. Hal ini mengindikasikan bahwa responden dengan tingkat self-compassion tinggi

Tabel 5. Hasil Analisis Koefisien Model Regresi Self-Compassion terhadap Burnout

\begin{tabular}{ccccccc}
\hline & \multicolumn{7}{c}{$\begin{array}{c}\text { 95\% Confidence } \\
\text { Interval }\end{array}$} \\
\hline \multicolumn{1}{c}{ Predictor } & B & SE & Lower & Upper & t & $\mathbf{p}$ \\
\hline Intercept & 39,164 & 2,340 & 34,513 & 43,815 & 16,735 & $<, 001$ \\
Self-Compassion & $-0,225$ & 0,023 & $-0,271$ & $-0,180$ & $-9,878$ & $<, 001$ \\
\hline
\end{tabular}

cenderung memiliki compassion satisfaction yang tinggi pula dan begitu juga sebaliknya.

Tabel 5 menunjukkan bahwa selfcompassion memiliki pengaruh yang signifikan terhadap burnout. Pengaruh ini bersifat negatif dan lemah $\left(B=-0,225, C l_{95}=[-0,271\right.$; $-0,180], S E=0,023, p<0,001)$. Dengan kata lain, semakin tinggi tingkat self-compassion maka burnout akan semakin rendah. 
Tabel 6. Hasil Analisis Koefisien Model Regresi Self-Compassion terhadap Secondary Traumatic Stress

\begin{tabular}{ccccccc}
\hline & \multicolumn{7}{c}{$\begin{array}{c}95 \% \text { Confidence } \\
\text { Interval }\end{array}$} \\
\hline \multicolumn{1}{c}{ Predictor } & B & SE & Lower & Upper & t & p \\
\hline Intercept & 42,671 & 3,206 & 36,298 & 49,044 & 13,308 & $<, 001$ \\
Self-Compassion & $-0,239$ & 0,031 & $-0,301$ & $-0,177$ & $-7,658$ & $<, 001$ \\
\hline
\end{tabular}

Informasi yang disajikan pada Tabel 6 menunjukkan bahwa self-compassion memiliki pengaruh signifikan yang bersifat negatif dan lemah terhadap secondary traumatic stress $\left(B=-0,239, \mathrm{Cl}_{95}=[-0,301\right.$; $-0,177], S E=0,031, p<0,001)$. Hal ini berarti peningkatan pada self- compassion akan diikuti dengan penurunan pada secondary traumatic stress.

\section{Pembahasan}

Penelitianinibermaksuduntukmengetahui secara empiris pengaruh self-compassion terhadap kualitas hidup profesional pada perawat jiwa, khususnya yang bekerja di RSJ Dr. Radjiman Wediodiningrat Lawang. Tantangan dan permasalahan yang dihadapi di tempat kerja membuat perawat jiwa berada dalam situasi penuh tekanan dan rentan mengalami stres. Stres yang berlebihan dapat berakibat pada burnout dan secondary traumatic stress. Hal ini dapat menurunkan kualitas hidup profesional mereka lalu berdampak pada berkurangnya kinerja perawat dan tingkat kesembuhan pasien. Self-compassion diasumsikan sebagai salah satu faktor psikologis yang mampu mendorong kualitas hidup profesional, yakni meningkatkan compassion satisfaction serta menurunkan burnout dan secondary traumatic stress.

Hasil analisis deskriptif menunjukkan bahwa tingkat self-compassion responden sebagian besar termasuk ke dalam kategori sedang. Responden cukup memiliki kecenderungan untuk peduli dan memahami diri sendiri ketika menghadapi penderitaan atau kegagalan, dan memandangnya sebagai hal yang umum dialami semua orang. Tingkat self-compassion yang dimiliki responden dalam penelitian ini lebih tinggi dibandingkan penelitian sebelumnya (Damayanti, 2014).

Kualitas hidup profesional responden secara umum tergolong baik dikarenakan mayoritas memiliki tingkat compassion satisfaction dalam kategori tinggi diikuti dengan compassion fatigue (burnout dan secondary traumatic stress) yang rendah. Responden dalam penelitian ini memiliki tingkat compassion satisfaction lebih tinggi dan compassion fatigue yang lebih rendah dibandingkan penelitian sebelumnya (Amelia et al., 2017). Menurut Stamm (2010), kondisi ini merepresentasikan individu yang memperoleh penguatan positif dari pekerjaannya. la tidak memiliki kekhawatiran yang signifikan tentang hambatan atau ketidakmampuan untuk bekerja secara efektif, juga tidak merasa ketakutan akibat pekerjaannya.

Hasil analisis data menunjukkan bahwa self-compassion berpengaruh secara signifikan terhadap aspek-aspek kualitas hidup profesional. Self-compassion menunjukkan pengaruh positif terhadap compassion satisfaction. Selain itu ditemukan bahwa self-compassion memiliki pengaruh negatif terhadap burnout dan secondary traumatic stress yang merupakan bagian dari compassion fatigue, dengan demikian hipotesis penelitian dapat diterima.

Pengaruh positif self-compassion terhadap compassion satisfaction mengindikasikan bahwa semakin tinggi tingkat selfcompassion maka semakin meningkat pula kepuasan yang dirasakan perawat jiwa karena dapat melakukan pekerjaan dengan baik, 
sementara pengaruh negatif self-compassion terhadap burnout dan secondary traumatic stress menunjukkan bahwa peningkatan pada self-compassion akan membuat burnout dan secondary traumatic stress semakin rendah.

Penemuan ini dapat dijelaskan dengan hasil penelitian sebelumnya yang mengungkap bahwa individu dengan selfcompassion mampu menerima, bersikap baik, dan menyadari apa yang sedang dialami dengan seimbang sehingga ketika menghadapi peristiwa buruk atau melihat penderitaan orang lain, ia dapat menanggapi kejadian tersebut secara objektif dan dengan keseimbangan emosi yang lebih besar (Abaci \& Arda, 2013; Germer \& Neff, 2013; Leary, Tate, Adams, Allen, \& Hancock, 2007; Neff \& Pommier, 2013).

Respon yang adaptif terhadap peristiwa tidak menyenangkan memperkecil kemungkinan bagi perawat jiwa untuk mengalami stres berlebihan yang dapat berakibat pada burnout dan secondary traumatic stress. Selain itu, meskipun perawat jiwa menemui pengalaman buruk ketika memberikan perawatan pada pasien, mereka tetap merasakan kepuasan dari melakukan tugas tersebut.

Hasil dalam penelitian ini mendukung penelitian sebelumnya yang menyatakan self-compassion memiliki pengaruh terhadap aspek-aspek kualitas hidup profesional pada perawat. Durkin dan kawan-kawan (2016) dalam penelitiannya terhadap perawat komunitas menyebutkan bahwa perawat yang berbelas kasih pada diri sendiri lebih kecil kemungkinannya untuk mengalami gejala burnout.

Studi yang dilakukan oleh Duarte dan kawan-kawan (2016) pada perawat di rumah sakit umum menjelaskan bahwa perawat yang mindful lebih merasakan kepuasan dari merawat pasien, sedangkan perawat yang bersikap terlalu menyalahkan diri sendiri, mengisolasi diri, dan terlalu larut dalam pengalaman tidak menyenangkan lebih rentan untuk mengalami compassion fatigue. Demikian pula yang ditemukan oleh Duarte dan Pinto-Gouveia (2017) pada perawat onkologi, bahwa self-compassion dapat memprediksi semakin tingginya compassion satisfaction dan semakin rendahnya compassion fatigue.

Clevenger (2018) juga menyebutkan pendapat yang serupa dengan temuan penelitian ini. la mengatakan self-compassion adalah hal yang penting untuk terapkan oleh tenaga kesehatan profesional karena self-compassion dapat meningkatkan kesejahteraan, kesehatan mental dan fisik, mengurangi kelelahan dan burnout, serta mendorong perawat untuk memberikan perawatan yang lebih baik pada pasien. Lebih lanjut, ia mengatakan kurangnya self-compassion dapat berakibat pada meningkatnya risiko mengalami compassion fatigue dan kepuasan kerja menurun. Tenaga kesehatan profesional yang menerapkan self-compassion cenderung merasakan keterhubungan sosial, keterbukaan terhadap ide-ide baru, dan kepuasan hidup yang lebih besar. Mereka juga merasakan berkurangnya kecemasan, depresi, rasa malu, dan takut akan kegagalan (Eriksson, Germundsjö, Åström, \& Rönnlund, 2018; Kemper, Mo, \& Khayat, 2015).

Penelitian mengenai keterkaitan selfcompassion terhadap kualitas hidup profesional pada perawat masih tergolong minim dan sulit ditemukan pada konteks perawat jiwa di Indonesia. Penelitian ini turut memberikan gambaran bahwa selfcompassion merupakan salah satu sikap yang penting dimiliki oleh perawat jiwa untuk mendorong kualitas hidup profesionalnya. Self-compassion meningkatkan compassion satisfaction dan menurunkan compassion fatigue (burnout dan secondary traumatic stress). Tingkat compassion satisfaction yang tinggi disertai dengan compassion fatigue yang rendah merupakan cerminan kualitas hidup profesional yang baik. 
Peran self-compassion terhadap aspek-aspek kualitas hidup profesional memunculkan kebutuhan untuk memberikan intervensi berupa edukasi dan penerapan selfcompassion. Intervensi ini dapat memberikan keuntungan pada perawat jiwa yang cenderung merasakan compassion fatigue yang tinggi dan membantu meningkatkan compassion satisfaction. Perawat jiwa dapat melatih kemampuan berbelas kasih pada diri sendiri dengan melakukan meditasi dan praktik mindfulness (Ducar, Penberthy, Schorling, Leavell, \& Calland, 2020; Eriksson et al., 2018; Gracia Gozalo et al., 2019; Sirgy \& Jackson, 2015). Hal lain yang dapat dilakukan adalah latihan menulis (Leary et al., 2007; Shapira \& Mongrain, 2010; Zhang \& Chen, 2016). Perawat dapat menulis peristiwa buruk yang pernah dialami kemudian merefleksikannya dengan konsep self-compassion. Perawat juga dapat melakukan yoga. Praktik yoga memberikan manfaat pada kesehatan fisik dan mental. Yoga diketahui dapat mendorong self-compassion dan mindfulness (Erkin \& Şenuzun Aykar, 2020).

Kualitas hidup profesional yang baik memberikan dampak positif bagi kesejahteraan perawat dan keberlanjutan pelayanan kesehatan jiwa. Perawat jiwa dapat bekerja dengan maksimal. juga meningkatkan produktivitas dan kepuasan kerjanya (Durkin et al., 2016; Murray, 2019). Lebih lanjut, studi sebelumnya membuktikan bahwa perawat dengan burnout yang rendah dan merasa puas terhadap lingkungan pekerjaan akan meningkatkan kepuasan dan kesembuhan pasien (Jang, Kim, \& Kim, 2016).

\section{Kesimpulan}

Berdasarkan hasil penelitian, dapat disimpulkan bahwa terdapat bukti selfcompassion memiliki pengaruh terhadap kualitas hidup profesional pada perawat jiwa. Semakin tinggi tingkat self-compassion, maka meningkat pula compassion satisfaction. Selain itu, semakin tinggi self-compassion maka burnout dan secondary traumatic stress akan semakin rendah.

Penelitian ini memiliki keterbatasan yaitu jumlah sampel tergolong sedikit dan penggunaan skala self-report memungkinkan adanya bias pada jawaban responden. Penelitian selanjutnya dapat dilakukan pada jangkauan area yang lebih besar agar hasilnya dapat digeneralisasikan ke populasi yang lebih luas. Selain itu, dapat menggunakan metode kualitatif dan/atau mempertimbangkan menguji faktor lain yang dapat memengaruhi kualitas hidup profesional.

\section{Ucapan Terima Kasih}

Peneliti mengucapkan terima kasih kepada berbagai pihak yaitu RSJ Dr. Radjiman Wediodiningrat Lawang yang telah memberi izin untuk menjadi lokasi penelitian ini, Hibatullah A. Farisi yang telah membantu selama pelaksanaan penelitian, dan para perawat yang telah bersedia menjadi responden penelitian.

\section{Daftar Pustaka}

Abaci, R., \& Arda, D. (2013). Relationship between Self-compassion and Job Satisfaction in White Collar Workers. Procedia - Social and Behavioral Sciences, 106, 2241-2247. https://doi. org/10.1016/j.sbspro.2013.12.255

Aji, A. B., \& Ambarini, T. K. (2014). Coping Stress Perawat dalam Menghadapi Agresi Pasien di Rumah Sakit Jiwa Dr. Radjiman Wediodiningrat Lawang. Jurnal Psikologi Industri Dan Organisasi, 3(1). http://journal.unair.ac.id/downloadfullpapers-jpioa53a2a93e2full.pdf

Amelia, A., Iswantoro, \& Chrisnawati. (2017). Faktor-faktor yang Berhubungan dengan Compassion Fatigue pada Perawat Jiwa di Ruang Rawat Inap Rumah Sakit Jiwa Sambang Lihum Kabupaten Banjar. JURNAL KEPERAWATAN SUAKA INSAN (JKSI), 3(1), 1-13. 
Andriani, D. A., Haryanti, F., \& Rustiyaningsih, A. (2017). Faktor-faktor yang Berhubungan dengan Compassion Satisfaction, Burnout, dan, Secondary Traumatic Stress Perawat di Ruang Perawatan Anak RSUP DR. Sardjito Yogyakarta. Tesis tidak dipublikasikan. Fakultas Kedokteran Universitas Gadjah Mada: Yogyakarta.

Clevenger, S. F. (2018). Is Self-Compassion Important for Health Care Practitioners? OBM Integrative and Complementary Medicine, 4(1), 1-11. https://doi.org/10. 21926/obm.icm.1901007

Coetzee, S. K., \& Klopper, H. C. (2010). Compassion fatigue within nursing practice: A concept analysis. Nursing and Health Sciences, 12(2), 235-243. https://doi.org/10.1111/j.1442-2018. 2010.00526.x

Damayanti, A. (2014). Studi Deskriptif Mengenai Self-Compassion pda Perawat Rumah Sakit Jiwa "X" di Kota Bandung. Skripsi tidak dipublikasikan. Fakultas Psikologi Universitas Kristen Maranatha: Bandung.

Debora, O., Ahsan, \& Kartikawatiningsih, D. (2017). Hubungan Lama Kerja dengan Professional Quality of Life Perawat di Instalasi Gawat Darurat RSUD dr. Iskak Tulung Agung. Medica Majapahit, 9(1), 49-58.

Duarte, J., \& Pinto-Gouveia, J. (2017). The role of psychological factors in oncology nurses' burnout and compassion fatigue symptoms. European Journal of Oncology Nursing, 28, 114-121. https:// doi.org/10.1016/j.ejon.2017.04.002

Duarte, J., Pinto-Gouveia, J., \& Cruz, B. (2016). Relationships between nurses' empathy, self-compassion and dimensions of professional quality of life: A crosssectional study. International Journal of Nursing Studies, 60, 1-11. https://doi. org/10.1016/j.jinurstu.2016.02.015
Ducar, D. M., Penberthy, J. K., Schorling, J. B., Leavell, V. A., \& Calland, J. F. (2020). Mindfulness for healthcare providers fosters professional quality of life and mindful attention among emergency medical technicians. Explore, 16(1), 61-68. https://doi.org/10.1016/j.explore. 2019.07.015

Durkin, M., Beaumont, E., Hollins Martin, C. J., \& Carson, J. (2016). A pilot study exploring the relationship between self-compassion, self-judgement, selfkindness, compassion, professional quality of life and wellbeing among UK community nurses. Nurse Education Today, 46, 109-114. https://doi. org/10.1016/j.nedt.2016.08.030

Eka, N. G. A., Tahulending, P., Kinasih, H. D., \& Yuningsih, I. (2016). Nurses' Professional Quality of Life in Final-Year Students. In I. H. Susilowati (Ed.), The 1st International Conference on Global Health (pp. 247-253). Depok: Faculty of Public Health Universitas Indonesia.

Eriksson, T., Germundsjö, L., Åström, E., \& Rönnlund, M. (2018). Mindful selfcompassion training reduces stress and burnout symptoms among practicing psychologists: A randomized controlled trial of a brief web-based intervention. Frontiers in Psychology, 9, 1-10. https:// doi.org/10.3389/fpsyg.2018.02340

Erkin, Ö., \& Şenuzun Aykar, F. (2020). The effect of the yoga course on mindfulness and self-compassion among nursing students. Perspectives in Psychiatric Care, 57(2), 875-882. https://doi.org/10. $1111 /$ ppc. 12630

Germer, C. K., \& Neff, K. D. (2013). Selfcompassion in clinical practice. Journal of Clinical Psychology, 69(8), 856-867. https://doi.org/10.1002/jclp.22021

Gracia Gozalo, R. M., Ferrer Tarrés, J. M., Ayora Ayora, A., Alonso Herrero, M., Amutio Kareaga, A., \& Ferrer Roca, R. (2019). Application of a mindfulness 
program among healthcare professionals in an intensive care unit: Effect on burnout, empathy and self-compassion. Medicina Intensiva (English Edition), 43(4), 207-216. https://doi.org/10.1016/j. medine.2019.03.006

Hamaideh, S. H. (2012). Occupational stress, social support, and quality of life among Jordanian mental health nurses. Issues in Mental Health Nursing, 33(1), 15-23. https://doi.org/10.3109/01612840.2011. 605211

Handini, F. S., Patarru', F., Weu, B. Y., Heryyanoor, H., \& Purwanza, S. W. (2019). Factors That Influence Professional Quality of Life (Pro-QOL) on Clinical Nurses. Jurnal Ners, 14(3), 393. https:// doi.org/10.20473/jn.v14i3.17176

Hegney, D. G., Rees, C. S., Eley, R., OsseiranMoisson, R., \& Francis, K. (2015). The contribution of individual psychological resilience in determining the professional quality of life of Australian nurses. Frontiers in Psychology, 6, 1-8. https:// doi.org/10.3389/fpsyg.2015.01613

Hikmah, N. (2015). Kualitas Hidup Perawat Jiwa Rumah Sakit Jiwa Dr. Radjiman Wediodiningrat Lawang (Universitas Airlangga). Skripsi tidak dipublikasikan. Fakultas Psikologi Universitas Airlangga: Surabaya.

Jang, I., Kim, Y., \& Kim, K. (2016). Professionalism and professional quality of life for oncology nurses. Journal of Clinical Nursing, 25(19-20), 2835-2845. https://doi.org/10.1111/jocn.13330

Joubert, P. D., \& Bhagwan, R. (2018). An empirical study of the challenging roles of psychiatric nurses at in-patient psychiatric facilities and its implications for nursing education. International Journal of Africa Nursing Sciences, 9, 49-56. https://doi. org/10.1016/j.ijans.2018.08.001

Kemper, K. J., Mo, X., \& Khayat, R. (2015). Are Mindfulness and Self-Compassion Associated with Sleep and Resilience in Health Professionals? The Journal of Alternative and Complementary Medicine, 21(8), 496-503. https://doi. org/10.1089/acm.2014.0281

Khamaisya, C. B. (2019). Hubungan antara Self-Compassion dengan Depresi pada Mahasiswa yang Sedang Mengerjakan Tugas Akhir. Skripsi tidak dipublikasikan. Fakultas Psikologi Universitas Airlangga: Surabaya.

Kholifah, S., Soeharto, S., \& Supriati, L. (2016). Hubungan Faktor-Faktor Internal Dengan Kejadian Kelelahan Mental (Burnout) Pada Perawat. Jurnal Kesehatan Mesencephalon, 2(4), 251259. https://doi.org/10.36053/mesen cephalon.v2i4.4

Leary, M. R., Tate, E. B., Adams, C. E., Allen, A. B., \& Hancock, J. (2007). Selfcompassion and reactions to unpleasant self-relevant events: The implications of treating oneself kindly. Journal of Personality and Social Psychology, 92(5), 887-904. https://doi.org/10.1037/00223514.92.5.887

McPhee, C. B. (2019). The Lived Experience Of Self-Compassion Among Registered Nurses In The Workplace. Disertasi tidak dipublikasikan. Teachers College, Columbia University: New York.

Muhith, A., Fardiansyah, A., \& Mawaddah, N. (2018). Hubungan Perilaku Kekerasan Pasien dengan Stres Perawat di Instalasi IPCU RSJ. Dr. Radjiman Wediodiningrat Lawang. Jurnal Ners Dan Kebidanan, 5(2), 137-143. https://doi.org/10.26699/ jnk.v5i2.ART.p137

Murray, D. D. (2019). Professional Quality of Life among Psychiatric Mental Health Nurses. Disertasi tidak dipublikasikan. D'Youville College: New York.

Neff, K. D. (2003a). Self-Compassion: An Alternative Conceptualization of a Healthy Attitude Toward Oneself. Self and Identity, 2, 85-101. https://doi. org/10.1016/s0761-8425(04)71291-7 
Neff, K. D. (2003b). The Development and Validation of a Scale to Measure Self-Compassion. Self and Identity, 2, 223-250. https://doi.org/10.1080/ 15298860390209035

Neff, K. D., \& Pommier, E. (2013). The Relationship between Self-compassion and Other-focused Concern among College Undergraduates, Community Adults, and Practicing Meditators. Self and Identity, 12(2), 160-176. https://doi. org/10.1080/15298868.2011.649546

Potter, P., Deshields, T., Divanbeigi, J., Berger, J., Cipriano, D., Norris, L., \& Olsen, S. (2010). Compassion fatigue and burnout: Prevalence among oncology nurses. Clinical Journal of Oncology Nursing, 14(5). https://doi.org/10.1188/10.CJON. E56-E62

Sabella, D., \& Fay-Hillier, T. (2014). Challenges in mental health nursing: current opinion. Nursing: Research and Reviews, 1-6. https://doi.org/10.2147/nrr.s40776

Sacco, T. L., \& Copel, L. C. (2018). Compassion satisfaction: A concept analysis in nursing. Nursing Forum, 53(1), 76-83. https://doi.org/10.1111/nuf.12213

Shapira, L. B., \& Mongrain, M. (2010). The benefits of self-compassion and optimism exercises for individuals vulnerable to depression. Journal of Positive Psychology, 5(5), 377-389. https://doi.or g/10.1080/17439760.2010.516763

Sirgy, M. J., \& Jackson, P. A. (2015). How to enhance the well-being of healthcare service providers and their patients? A mindfulness proposal. Frontiers in Psychology, 6(MAR), 1-3. https://doi. org/10.3389/fpsyg.2015.00276

Stamm, B. H. (2009). Professional Quality of Life: Compassion Satisfaction and Fatigue Version 5 (ProQOL). diterima 31 Mei 2020 dari: https://proqol.org/ ProQol_Test.html

Stamm, B. H. (2010). The concise ProQOL manual. In Pocatello, ID: ProQOL. org. diterima 31 Mei 2020 dari: http://proqol.org/uploads/ProQOL_ Concise_2ndEd_12-2010.pdf

Turgoose, D., \& Maddox, L. (2017). Predictors of compassion fatigue in mental health professionals: A narrative review. Traumatology, 23(2), 172-185. https:// doi.org/10.1037/trm0000116

Varghese, B. (2020). Relationships between positive and negative attributes of selfcompassion and perceived caring efficacy among psychiatric-mental health nurses. Journal of Psychosocial Nursing and Mental Health Services, 58(2), 3240. https://doi.org/10.3928/0279369520191022-01

Yosep, I., Putit, Z., Hazmi, H., \& Mediani, H. S. (2016). Exposure of Mental Health Nurses to Violence in Mental Hospital : a Systematic Review Terpaparnya Perawat Jiwa terhadap Kekerasan di Rumah Sakit Jiwa: Sistematik Review. Jurnal Keperawatan Padjadjaran, 4(3), 293-304.

Yusuf, A. H., Fitryasari, R., Nihayati, H. E., \& Tristiana, R. D. (2019). Kesehatan Jiwa: Pendekatan Holistik dalam Asuhan Keperawatan. Surabaya: Mitra Wacana Media.

Zhang, J. W., \& Chen, S. (2016). SelfCompassion Promotes Personal Improvement From Regret Experiences via Acceptance. Personality and Social Psychology Bulletin, 42(2), 244-258. https://doi.org/10.1177/014616721 5623271 